\title{
Volume Transport Variability in the Western Equatorial Pacific and its Relations to Halmahera Throughflow
}

\author{
Marlin Chrisye Wattimena ${ }^{1 *}$, Agus Saleh Atmadipoera ${ }^{1}$, Mulia Purba ${ }^{1}$, \\ I Wayan Nurjaya ${ }^{1}$ and Fadli Syamsudin ${ }^{2}$ \\ ${ }^{1}$ Department of Marine Science and Technology, Faculty of Fisheries and Marine Sciences, IPB University \\ Bogor, 16680 Bogor, West Java, Indonesia \\ ${ }^{2}$ The Agency for the Assessment and Application of Technology (BPPT), 10340 Jakarta, Indonesia
}

\begin{abstract}
This study investigates the coherency of volume transport between Halmahera throughflow and current major system in the western equatorial Pacific Ocean (Mindanao Current - MC, New Guinea Coastal/Under Current - NGCC/NGCUC, and North Equatorial Counter Current - NECC). The validated daily ocean general circulation model datasets of INDESO (2010-2014) were used in this study. The results showed that the estimated average transport volume was 25.6 Sv flowing southward through MC, $34.5 \mathrm{~Sv}$ flowing eastward through NECC, 18.3 Sv flowing northwestward through NGCC/NGCUC, and 2.5 Sv flowing southward through the Halmahera Sea. The variability of volume transport was dominated by intraseasonal, semiannual, and annual time-scales. The increased transport of NECC corresponded to the intensification of MC and NGCC/NGCUC transports. NGCC/ NGCUC significantly controlled the South Pacific water inflow into the Halmahera Sea because of the positively high correlation between NGCC/NGCUC transport and Halmahera throughflow transport.
\end{abstract}

Keywords: Cross-PSD, Halmahera throughflow, INDESO model, Western Equatorial Pacific

\author{
ARTICLE INFO \\ Article history: \\ Received: 12 November 2020 \\ Accepted: 11 January 2021 \\ Published: 30 April 2021 \\ DOI: https://doi.org/10.47836/pjst.29.2.26 \\ E-mail addresses: \\ marlinchrisyewattimena@gmail.com (Marlin Chrisye Wattimena) \\ atmadipoera_itk@apps.ipb.ac.id (Agus Saleh Atmadipoera) \\ mpsiboro@yahoo.com (Mulia Purba) \\ wayan2011@gmail.com (I Wayan Nurjaya) \\ fadlihiro@yahoo.com (Fadli Syamsudin) \\ * Corresponding author
}

\section{INTRODUCTION}

The Pacific low-latitude western boundary current (LLWBC) plays a significant role in controlling Pacific circulation where the water mass from the northern and southern hemispheres accumulate (Lukas et al., 1996); hence, affecting the global climate due to mass and heat transport balances from sub-tropical area to tropical area and from 
the Pacific Ocean to Indian Ocean (Hu et al., 2015). These oceanographic roles of LLWBC are of interest to regional oceanographic studies affected by LLWBC. The previous studies remarkably described LLWBC pathways such as Mindanao Current (MC), North Equatorial Counter Current (NECC), New Guinea Coastal Current (NGCC) and New Guinea Coastal Undercurrent (NGCUC), Mindanao Eddies (ME) and Halmahera Eddies (HE) (Kashino et al., 2011; Kashino et al., 2013).

Numerous studies have reported the importance of LLWBC in water transport in Indonesian waters via Indonesian throughflow (ITF). LLWBC has been found to accumulate in the western equatorial Pacific with complex water distribution (Figure 1). From the north, MC flows southward along the eastern Philippine coast (Lukas \& Lindstrom, 1991; Gordon \& Fine, 1996; Wijffels et al., 1995; Kashino et al., 2005) and contributes to Indonesian Throughflow (ITF) and NECC (Fine et al., 1994; Lukas et al., 1996; Kashino et al., 2001). NGCC/NGCUC flows northwest through the New Guinea coast from the southern hemisphere (Kuroda, 2000; Ueki et al., 2003; Kashino et al., 2007). These currents are jointed around eastern Halmahera islands, and some of these water masses entering Indonesian waters are known as ITF. At the same time, the rest flows eastward as NECC from the western Pacific to the east.

ITF is the only inter-ocean current present in low latitude. It flows from the Pacific Ocean to the Indian Ocean, being a part of the global thermohaline circulation cycle. The ITF water mass source is dominantly from North Pacific via MC and south Pacific via NGCC (Wyrtki, 1961; Gordon \& Fine, 1996; Ilahude \& Gordon, 1996; Gordon, 2005). Due to the location of the Halmahera Sea adjacent to the Western Pacific, the water mass of Halmahera Sea is likely to be affected by the LLWBC system despite the complexity of LLWBC current system close to the Halmahera Sea, which is challenging to study based on the model outputs, the relationship between the currents in the LLWBC system and inputs to the Halmahera Sea. Some previous studies have examined the structure and variability of MC, NGCC, NGCUC, NECC, HE, and ME, as part of LLWBC (Lukas \& Lindstrom, 1991; Gouriou \& Toole, 1993; Fine et al., 1994; Wijffels et al., 1995; Arruda \& Nof, 2003; Atmadipoera et al., 2004; Kashino et al., 2007, 2013; Harsono et al., 2014, Wattimena et al., 2018). Many have been studied from the results of observation and modeling. Estimated volume transport from each LLWBC system branch has also been examined previously from the effects of observations and modeling. Estimates of Mindanao Current transport have ranged from 8 to $40 \mathrm{~Sv}$ (Lukas, 1988; Qu et al., 1998, Kashino et al., 2009). Most earlier studies focused only on one or two branches of the LLWBC system.

Despite studies in the Halmahera Sea related to LLWBC, the connection between LLWBC and the Halmahera Sea, such as the variability of Halmahera throughflow associated with LLWBC, is still unknown. The relationship of NGCC with input to the Halmahera Sea in the upper $200 \mathrm{~m}$ depth was previously reported by Wattimena et al. (2018). 
Still, it did not account for the influence of other LLWBC current systems. The present study will estimate volume transport and describe the variability and connection between Halmahera throughflow and Pacific low latitude western boundary current (MC, NECC, and NGCC/NGCUC). The study area comprised of a transect in the eastern Philippine at $7^{\circ} \mathrm{N}\left(126^{\circ} \mathrm{E}-130^{\circ} \mathrm{E}\right)$ representing $\mathrm{MC}$, a transect at $133^{\circ} \mathrm{E}\left(2.0^{\circ} \mathrm{N}-7.0^{\circ} \mathrm{N}\right)$ representing $\mathrm{NECC}$, a transect in North New Guinea at $133^{\circ} \mathrm{E}\left(0.5^{\circ} \mathrm{S}-2.0^{\circ} \mathrm{N}\right)$ representing NGCC/ NGCUC, and a transect in the Halmahera Sea at $0.3^{\circ} \mathrm{S}\left(127.8^{\circ} \mathrm{E}-130.4^{\circ} \mathrm{E}\right)$ (Figure 1).

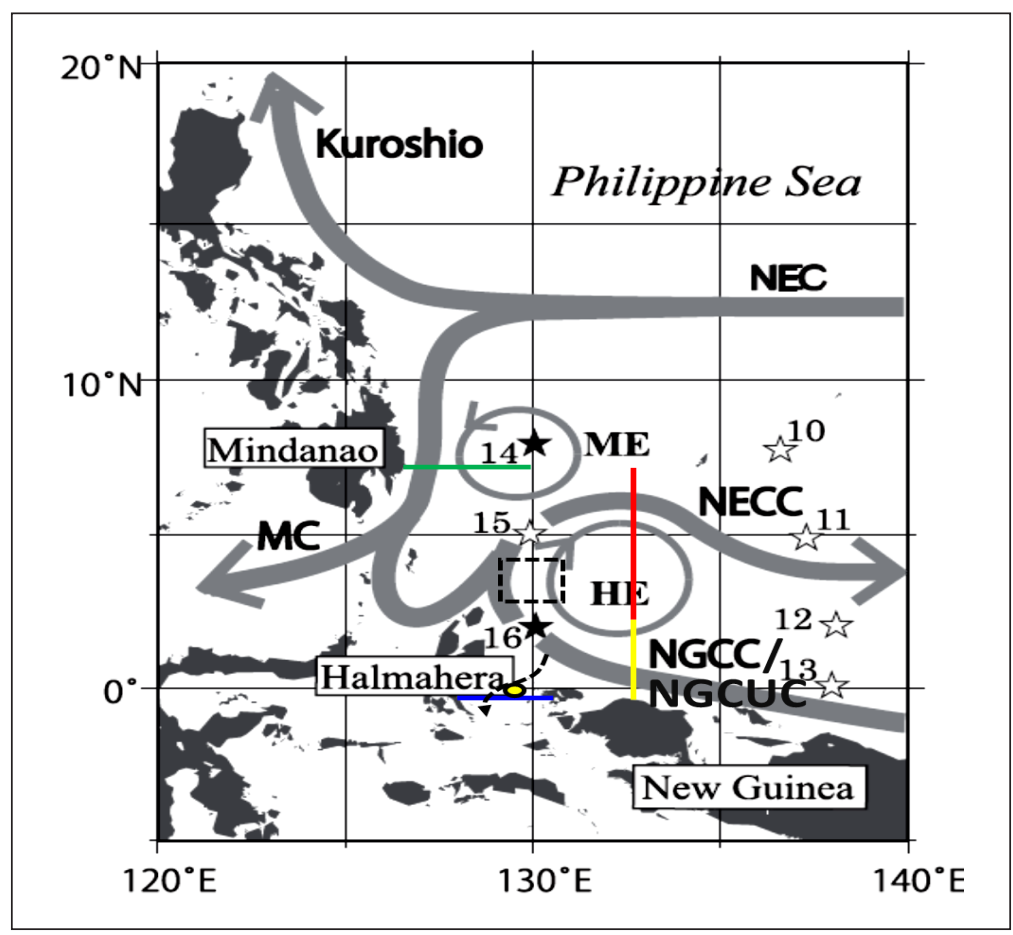

Figure 1. Main current circulation of LLBWC (adapted from Kashino et al., 2013). Blue line: representing transect of Halmahera throughflow. Yellow line: representing transect of NGCC/NGCUC. Red line: representing transect of NECC. Green line: representing transect of MC. Dashed line representing inflow to Halmahera Sea. Dash black box and yellow circle representing satellite and mooring INDOMIX location. Numbers and stars represent TRITON buoys array.

\section{MATERIALS AND METHODS}

\section{INDESO Model Output}

The numerical outputs in this study used the simulations of Ocean General Circulation Model (OGCM) with Infrastructure Development for Space Oceanography (INDESO) configuration within the domain model in Indonesian Seas $\left(90^{\circ} \mathrm{E}-145^{\circ} \mathrm{E} ; 25^{\circ} \mathrm{S}-20^{\circ} \mathrm{N}\right)$, such as detailed bathymetry, direct tidal forcing and mixing parameterization. Mercator Ocean developed INDESO, a scientific program in cooperation with Collecte Localisation 
Satellites (CLS) in Toulouse, France, to produce data for the Ministry of Marine Affairs and Fisheries. INDESO used Mercator Ocean System and Interface Relocatable Nesting (SIREN) tools to create a new and more significant configuration by combining bathymetry, initial condition, and boundary condition (Theetten et al., 2014). INDESO model used in-situ and satellite measurements as its simulation inputs. Data for the INDESO model were collected during the INDOMIX expedition. Bahurel and Mercator (2006) detailing some data used to build, assimilate, and validate the model.

The domain model of this study covers the Western Equatorial Pacific and Halmahera Sea $\left(125^{\circ} \mathrm{E}-144^{\circ} \mathrm{E} ; 4^{\circ} \mathrm{S}-15^{\circ} \mathrm{N}\right)$, with 3 -dimension parameters including temperature, salinity, and current (zonal and meridional components) and sea surface height from January 2010 to December 2014. Temporal resolution was daily, with a horizontal resolution of $1 / 12^{\circ}$ (about $9.25 \mathrm{~km}$ ). INDESO applied 50 vertical layers with the high-resolution discretization density near the surface layer. In the first $10 \mathrm{~m}$, the layer thickness is less than $2 \mathrm{~m}$, then raised to about 10 to $50 \mathrm{~m}$ depth. Modeled temperature and salinity are overlaid with the current in the same grids to describe the central circulation around the Low Latitude Western Boundary Pacific and the Halmahera Sea (study area). The estimated transport volume (Sv) is calculated using zonal and meridional velocity data according to the orientation of the current components that are dominant in each transect. The formula for transport estimation will be explained in the data analysis section.

\section{Datasets Used for Validating INDESO Model}

Observations used in the INDESO model are described as follows. For validating ocean currents, the study used meridional ocean currents observed from an ADCP INDOMIX mooring point in the Halmahera Sea (yellow circle in Figure 1) within $200 \mathrm{~m}-700 \mathrm{~m}$ from July 2010 to December 2012 (Atmadipoera et al., 2013). For the sea surface height anomaly (SSHA) dataset, AVISO altimetry products (spatial resolution of $1 / 4^{\circ}$ ) were used with dataset range between January 2008 and December 2014. The GHRSST-PP satellite observed measurements (spatial resolution of $1 / 20^{\circ}$ ) were used to validate the modeled SST.

\section{Data Analysis}

The characteristics and variability of ocean currents in the study area were assessed using time-series analysis through the determination of the average current, continuous wavelet transform (CWT), and cross-correlation as previously performed by Emery and Thomson (2014) and Bendat and Piersol (2010). The averaged ocean currents were determined to investigate the general spatial circulation pattern in the area. The climatological method was carried out to analyze the annual cycle from volume transports of MC, NECC, NGCC, and Halmahera throughflow. The CWT analysis was used to assess the temporal variability of MC, NECC, NGCC, and Halmahera throughflow transport. 
Transport volume estimation of MC, NECC, NGCC/NGCUC, and Halmahera throughflow was calculated by establishing transects that passed through the eastern Philippines at $7^{\circ} \mathrm{N}\left(126^{\circ} \mathrm{E}-128.5^{\circ} \mathrm{E}\right)$ representing $\mathrm{MC}$, at $133^{\circ} \mathrm{E}\left(2.0^{\circ} \mathrm{N}-7.0^{\circ} \mathrm{N}\right)$ representing NECC, in North New Guinea at $133^{\circ} \mathrm{E}\left(0.5^{\circ} \mathrm{S}-2.0^{\circ} \mathrm{N}\right)$, and in the Halmahera Sea at $0.3{ }^{\circ} \mathrm{S}\left(127.8^{\circ} \mathrm{E}-130.4^{\circ} \mathrm{E}\right)$ (Eqiation 1 - 4). The estimation in each area was calculated by integrating zonal velocity $(u)$ to determine the estimated volume transport of NECC and NGCC/NGCUC $(Q u)$. The meridional rate $(v)$ was incorporated to determine the volume transports of $\mathrm{MC}$ and Halmahera throughflow $(Q v)$, considering the transect length and depth, as described by Emery and Thomson (2014):

$$
\begin{aligned}
& Q v_{M C}=\int_{126 \mathrm{E}}^{128.5 \mathrm{E}} \int_{700 m}^{0} v d z \\
& Q u_{N E C C}=\int_{2 \mathrm{~N}}^{7 \mathrm{~N}} \int_{1142 m}^{0} u d z \\
& Q u_{N G C C / N G C U C}=\int_{0.5 \mathrm{~S}}^{2 \mathrm{~N}} \int_{832 m}^{0} u d z \\
& Q v_{\text {Halmahera }}=\int_{127.8 \mathrm{E}}^{130.5 \mathrm{E}} \int_{700 m}^{0} v d z
\end{aligned}
$$

Where $Q u_{N E C C}$ (unit in $\mathrm{Sv} ; 1 \mathrm{~Sv}=10^{6} \mathrm{~m}^{3} / \mathrm{s}$ ) is the total volume transport of NECC that intersects the NECC transect line; $Q u_{N G C C / N G C U C}$ is the total volume of NGCC/NGCUC that intersects the NGCC/NGCUC transect line; $Q v_{M C}$ is the total volume of MC that intersects the MC transect line; $Q v_{\text {HALMAHERA }}$ is the total volume of Halmahera throughflow that intersects transect line in eastern Halmahera. Vertically, the lower limits of the integration calculation of transport were $700 \mathrm{~m}, 1142 \mathrm{~m}, 832 \mathrm{~m}$ and $700 \mathrm{~m}$, respectively for MC, NECC, NGCC/NGUCC and Halmahera at which the zero-velocity contour was located.

Cross-correlation analysis of the anomaly of transport in each area was performed with the following combinations: MC - NECC, MC - NGCC/NGCUC, MC - Halmahera, NECC-Halmahera, NGCC/NGCUC - NECC, and NGCC/NGCUC - Halmahera. The analysis resulted in energy co-spectrum, coherence, and phase difference. The energy cospectrum indicates the magnitude of shared energy fluctuation at a specific frequency within two time-series. Meanwhile, coherence represents the correlation and phase difference, indicating the difference in time interval within both variables (Bendat \& Piersol, 2010). 


\section{Model Validations}

INDESO model has significantly agreed with observations. For example, INDESO-TAO TRITON comparison, correlation coefficients and RMSE for zonal (meridional) velocities are $0.74(0.7)$ and $0.25 \mathrm{~m} / \mathrm{s}(0.21 \mathrm{~m} / \mathrm{s})$, respectively (Figure 2a). Similarly, the correlation coefficients and RMSE for SST (SSHA) are $0.85(0.8)$ and $0.6{ }^{\circ} \mathrm{C}(0.03 \mathrm{~m})$ between INDESO model and satellite observations (Figure 2c and 2d). Besides, the depth-time distributions of meridional velocities of INDESO are also qualitatively agreeable with a

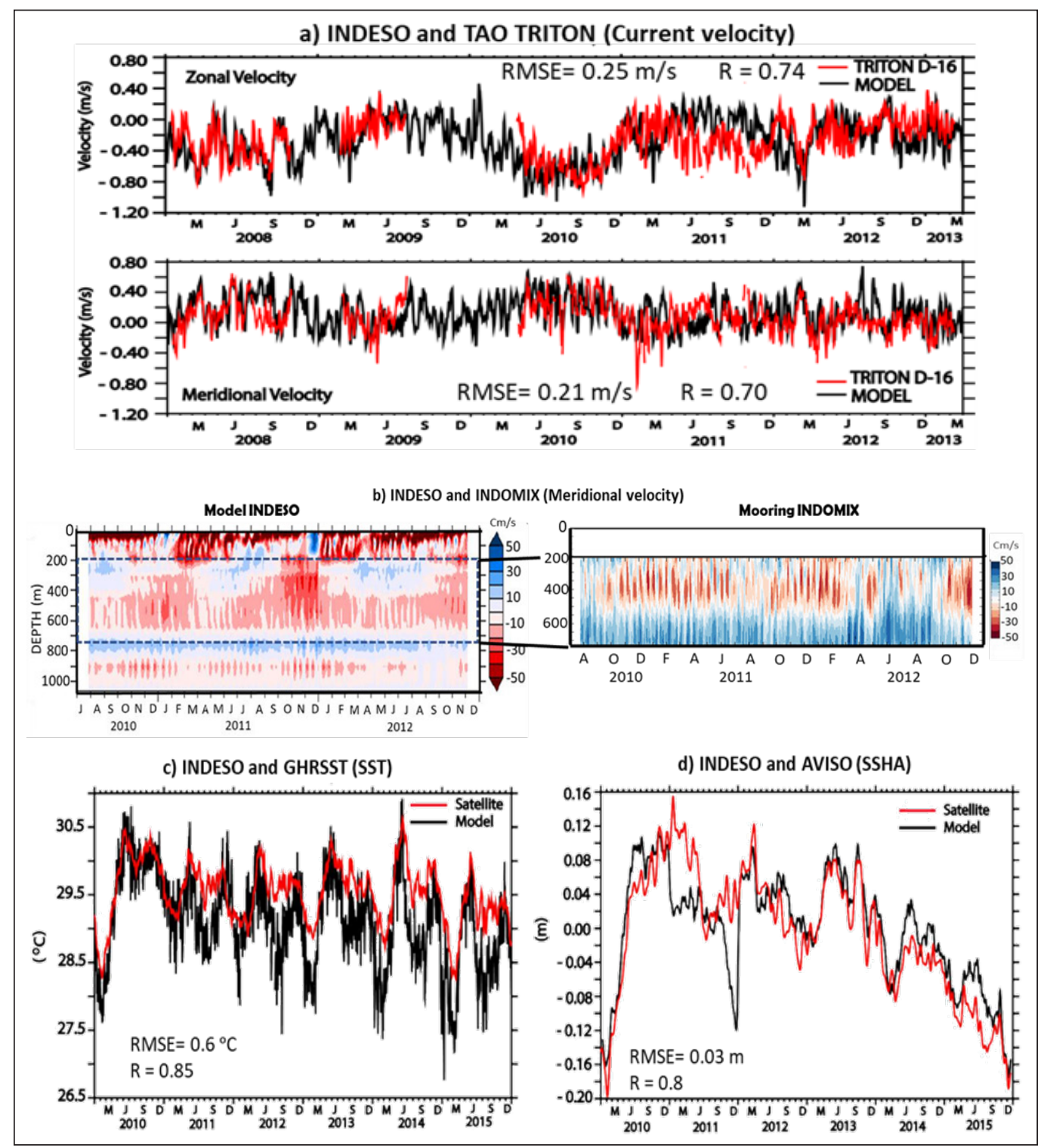

Figure 2. INDESO model output compared with (a) TAO TRITON; (b) INDOMIX; (c) SST and (d) SSHA. 
single ADCP INDOMIX (Figure 2b). It is noted that the single moored 75-kHz ADCP was placed unexpectedly much deeper on the seabed at about $760 \mathrm{~m}$ depth, thus the current data in the upper $200 \mathrm{~m}$ depth cannot be measured by the instrument. The validations of INDESO model with ADCP show that there are southward flows within 200-400 m with the core flow at $400 \mathrm{~m}$. This southward flow is due to the undercurrent of NGCUC, moving underneath NGCC along the back of Papuan coasts and ultimately reaching Halmahera. The validations of temporal changes between INDESO model and ADCP data show that the model replicate southward flows within 200-400 m with the core flow at $400 \mathrm{~m}$ as shown by ADCP data with strong intraseasonal variability evident at sub-thermocline layer. The general model validation of the INDESO model output has also been described in Tranchant et al. (2015).

\section{RESULTS}

\section{General Circulation of LLWBC}

Figure 3 shows the general circulations of LLWBC coupled with temperature and salinity at certain depths ( $25 \mathrm{~m}, 100 \mathrm{~m}, 200 \mathrm{~m}$, and $300 \mathrm{~m}$ ) and was long time averaged of all datasets. The LLWBCs area is a confluence region of current branches originating from the North Pacific and South Pacific. The overlays of averaged current vectors, salinity (left panel of Figure 3), and temperature (right panel of Figure 3) at depths of $25 \mathrm{~m} \mathrm{(a),} 100 \mathrm{~m}$ (b), $200 \mathrm{~m}$ (c), and $300 \mathrm{~m}$ (d) from January 2010 to December 2014 showed two main streams of the western Equator Pacific current system: MC and NGCC / NGCUC. MC flowed southward along the east coast of Mindanao to the Pacific equator. MC's existence as the source input of ITF through the Sulawesi Sea and then forwarded to the Makassar Strait (and through the Maluku Sea) was visible in the flow vector model results from depths. MC transports a water mass characterized by low salinity from the subtropical region $(\mathrm{S}=34.6-34.9)$ with temperature ranging from $20^{\circ} \mathrm{C}$ to $24^{\circ} \mathrm{C}$. Below the thermocline $(300 \mathrm{~m})$ in $\mathrm{MC}$, water mass was characterized by salinity and temperature of $34.3-34.5$ and $9{ }^{\circ} \mathrm{C}-12{ }^{\circ} \mathrm{C}$, respectively. NGCC / NGCUC is the incoming inflow from the South Pacific Ocean. NGCC/NGCUC is part of the SEC that moves towards the Pacific region to the northwest along the back of Papua - New Guinea. NGCC carries high-salinity water (35.0 - 35.5) at temperatures of $18{ }^{\circ} \mathrm{C}-26^{\circ} \mathrm{C}$. In addition to the MC and NGCC/NGCUC that make up LLWBC, there are also NECC current branches that appear to result from the confluence region of two main current branches. NECC flows from the western edge of the Pacific to the eastern Pacific. Surface circulation ( $25 \mathrm{~m}$ ) showed the presence of HE and ME. At a depth of 100 m, $200 \mathrm{~m}$, and $300 \mathrm{~m}$, in addition to HE and ME, New Guinea Eddies (NGE) was also seen (Kashino et al., 2007). However, at a depth of $300 \mathrm{~m}$, the NGE began to weaken. The circulation pattern showed the South Pacific water entered through the Halmahera Sea and the Maluku Sea into the Seram Sea, then forwarded to the Banda Sea. 


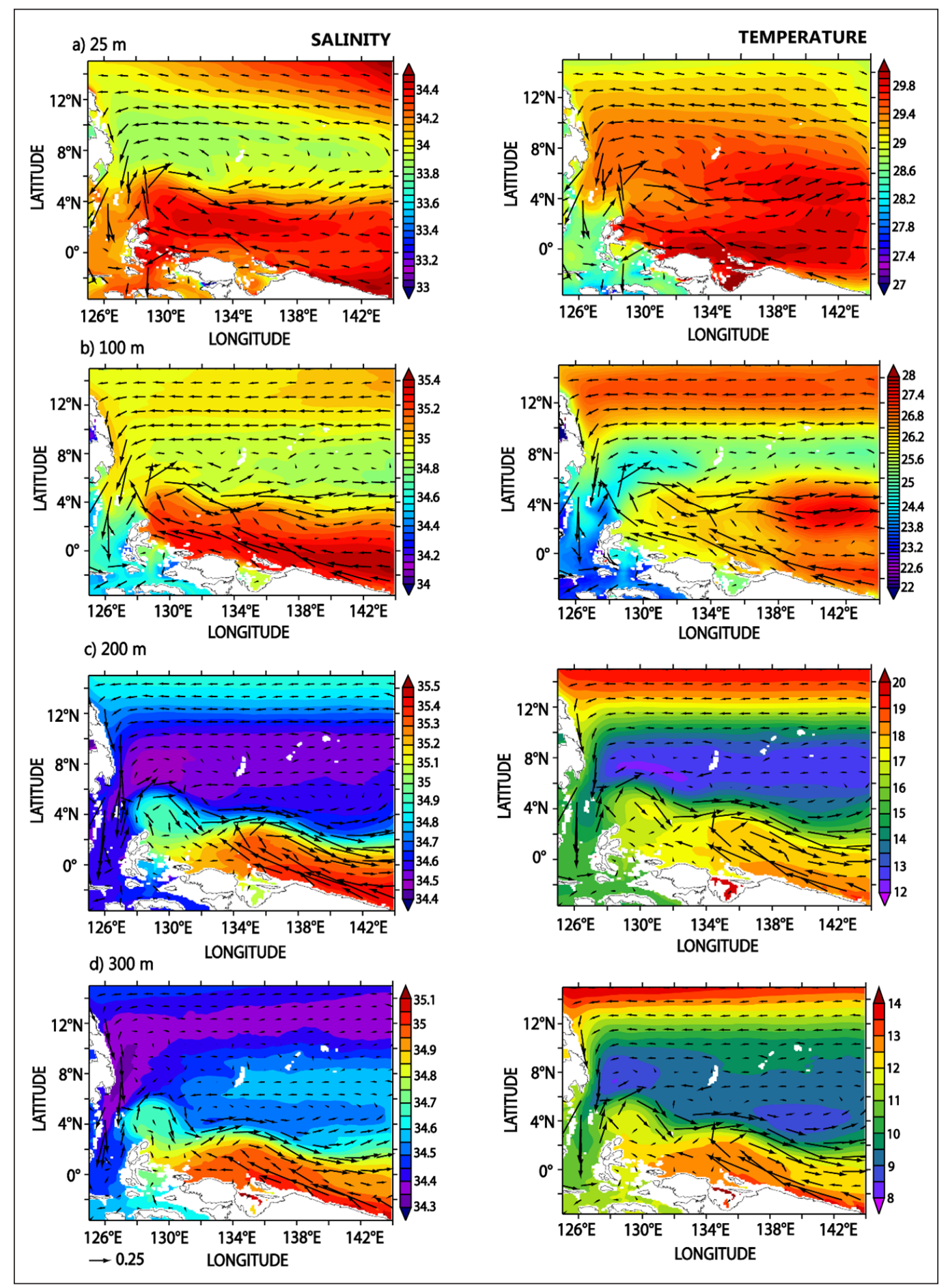

Figure 3. Mean ocean circulation pattern of Western Pacific, averaged from January 2010 to December 2014. The overlay result of average current vector with salinity (left) and temperature (right) at various depth levels: (a) $25 \mathrm{~m}$; (b) $100 \mathrm{~m}$; (c) $200 \mathrm{~m}$; and (d) $300 \mathrm{~m}$. 


\section{Seasonal Circulation of LLWBC}

Similar to Figure 3, Figure 4a and 4b illustrate the mean seasonal circulations of LLWBC in winter (January) and summer (August) seasons, respectively. Strong Seasonal variation in LLWBC was evident from INDESO model between winter and summer conditions. At the surface layer $(25 \mathrm{~m}$ and $100 \mathrm{~m}), \mathrm{MC}$ transports less salty, cooler water $(\mathrm{S}=33.7-34.8$; $\left.\mathrm{T}=28{ }^{\circ} \mathrm{C}-28.6{ }^{\circ} \mathrm{C}\right)$ in winter than in summer $\left(\mathrm{S}=33.8-35 ; \mathrm{T}=28{ }^{\circ} \mathrm{C}-30{ }^{\circ} \mathrm{C}\right) . \mathrm{MC}$ is faster particularly at the flow along east coasts of Philippines in summer than in winter. The bifurcation of $\mathrm{MC}$ is located at $12^{\circ} \mathrm{N}$ during summer and winter. At the depths of 200 $\mathrm{m}$ and $300 \mathrm{~m}$, the flow of $\mathrm{MC}$ weakens in the winter $\left(\mathrm{S}=34.6-34.4 ; \mathrm{T}=14-16^{\circ} \mathrm{C}\right)$ compared to in the summer with salinity and temperature respectively $34.6-34.9$ and $10-20^{\circ} \mathrm{C}$. NECC flow also shows a seasonal variability. In winter (Figure 4a), NECC flowing toward east Pacific at $4^{\circ} \mathrm{N}, 129^{\circ} \mathrm{E}$. This flow is formed by the overturning of NGCC/NGUCC carrying salty water (34.5) that hence meets $\mathrm{MC}$ with low salinity. In contrast, in summer, the establishment of NECC is slightly northward (around $6^{\circ} \mathrm{N}, 128^{\circ} \mathrm{E}$ ) with less salty, warmer water $\left(\mathrm{S}=34 ; \mathrm{T}=30^{\circ} \mathrm{C}\right.$ ). NGCC/NGUCC varies seasonally. In summer (Figure $4 \mathrm{~b}$ ), at the top $100 \mathrm{~m}, \mathrm{NGCC}$ flowing north-westward is intensified. In contrast, in winter, this flow weakens, causing this flow to turn to southeast. NGUCC (below $100 \mathrm{~m}$ ) flowing to northwest is intensified in summer and its direction is also maintained in winter. NGE establishes at $4^{\circ} \mathrm{N}, 134^{\circ} \mathrm{E}$ with the larger flow magnitude found in summer than in winter. Halmahera throughflow is intensified in summer than in winter. The weak flow of this current system in winter causes some overflow in Pacific Ocean.

\section{Vertical Structure of the Current}

Characteristics of flows in each branch of LLWBC and Halmahera are shown from the mean and standard deviation presented in Figure 5. Dimensions of $\mathrm{MC}$ flow with an average meridional component at $7^{\circ} \mathrm{N}$ directing to the south appeared to widen from the eastern gate of Mindanao to $128^{\circ} \mathrm{E}$, with a current thickness of $700 \mathrm{~m}$. MC's core velocity reached $>1 \mathrm{~m} / \mathrm{s}$ from surface to $250 \mathrm{~m}$ depth (Figure $5 \mathrm{a}$ ). The average zonal velocity along $133^{\circ} \mathrm{E}$ representing the NECC demonstrated a high current velocity to the east. The NECC flows between $2^{\circ} \mathrm{N}-6^{\circ} \mathrm{N}$, reaching a depth of $>1100 \mathrm{~m}$. The NECC core was found at $4^{\circ} \mathrm{N}$, reaching a maximum velocity of $>0.5 \mathrm{~m} / \mathrm{s}$ a depth of $150 \mathrm{~m}$ (Figure $5 \mathrm{~b}$ ). The average zonal current component along $133^{\circ} \mathrm{E}$ showed that NGCC/NGCUC flow demonstrated a high speed, dominantly flowing to the west. Additionally, the core dimension of NGCC was observed to widen from North New Guinea to $2^{\circ} \mathrm{N}$. It was found to be closed to surface up to $200 \mathrm{~m}$ depth. The maximum flow rate of NGCC was found at $>0.5 \mathrm{~m} / \mathrm{s}$, a depth of $100 \mathrm{~m}$ (Figure 5c). NGCUC flow was found below NGCC until up to $800 \mathrm{~m}$ depth. In terms of the current meridional component at $0.3^{\circ} \mathrm{S}$, the flow east of the Halmahera Sea showed the current's high speed, dominantly entering into the south. This flow is an 


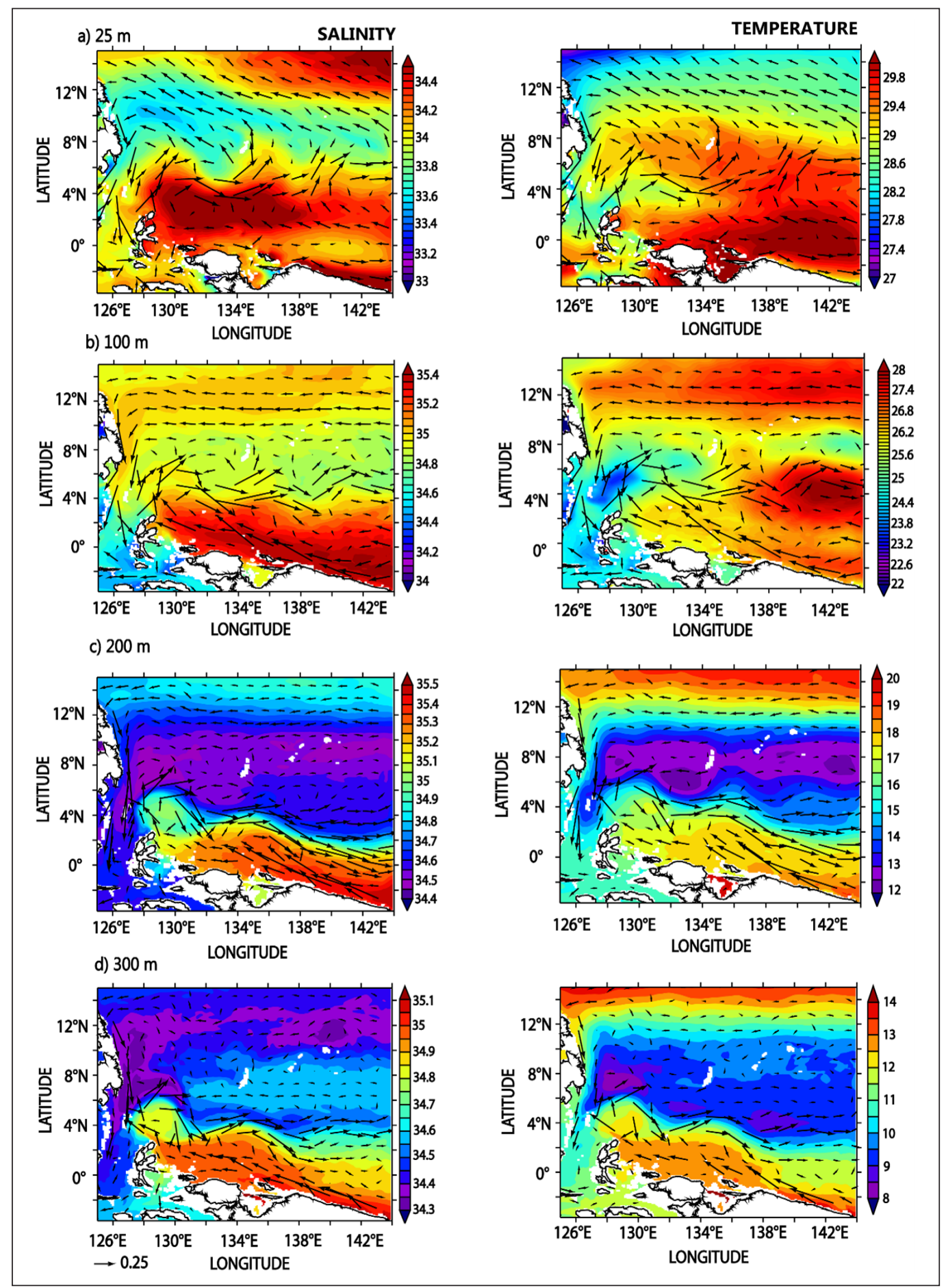

Figure $4 a$. Winter circulation pattern of Western Pacific. The overlay result of average current vector with salinity (left) and temperature (right) at various depth levels: (a) $25 \mathrm{~m}$ (a); (b) $100 \mathrm{~m}$, (c) $200 \mathrm{~m}$ (c) and (d) $300 \mathrm{~m}$. Note, the profiles were the average of December, January and February datasets. 


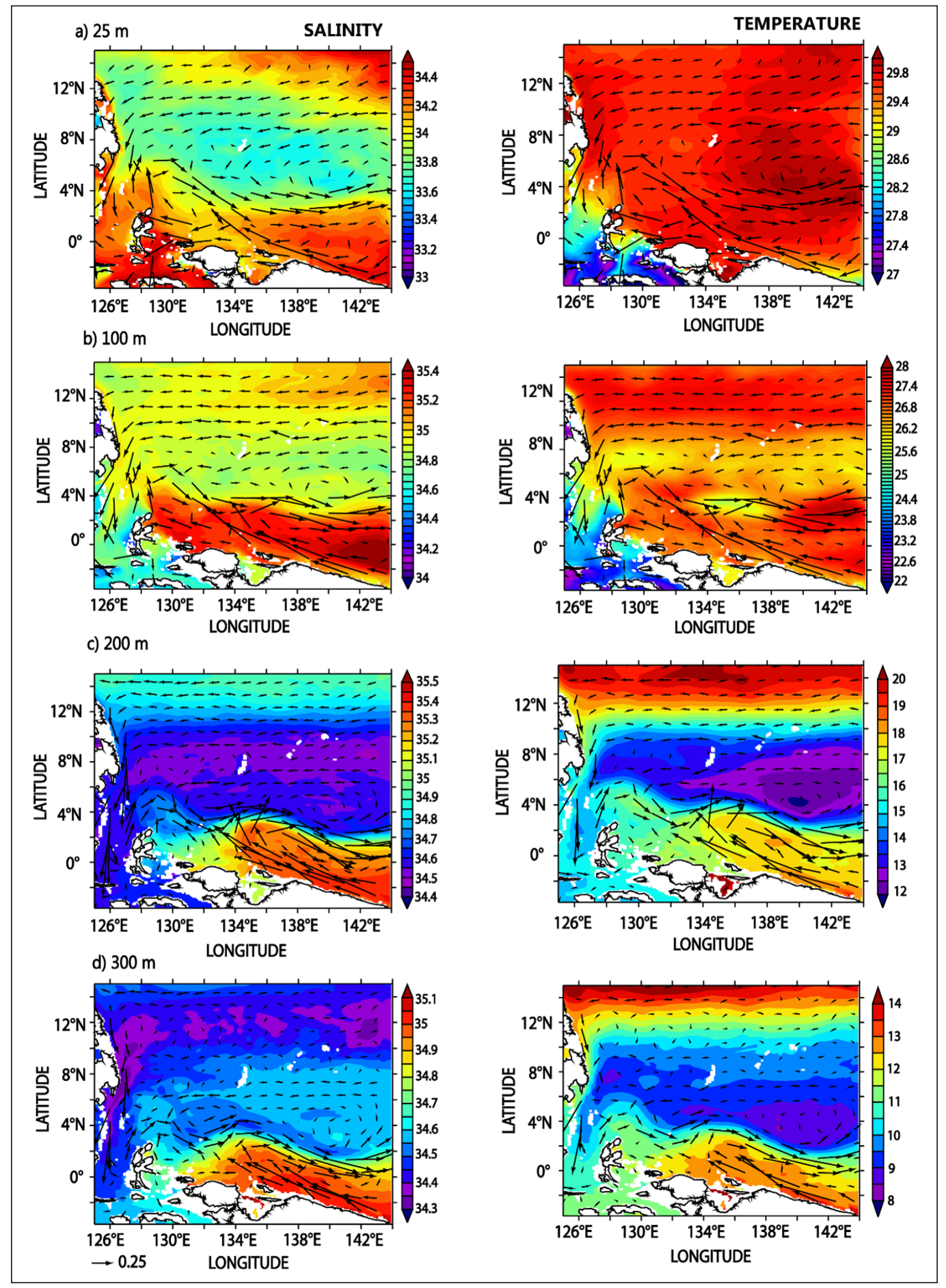

Figure $4 b$. Summer circulation pattern of Western Pacific. The overlay result of average current vector with salinity (left) and temperature (right) at various depth levels: (a) $25 \mathrm{~m}$; (b) $100 \mathrm{~m}$; (c) $200 \mathrm{~m}$ and (d) $300 \mathrm{~m}$. Note, the profiles were the average of June, July and August datasets. 


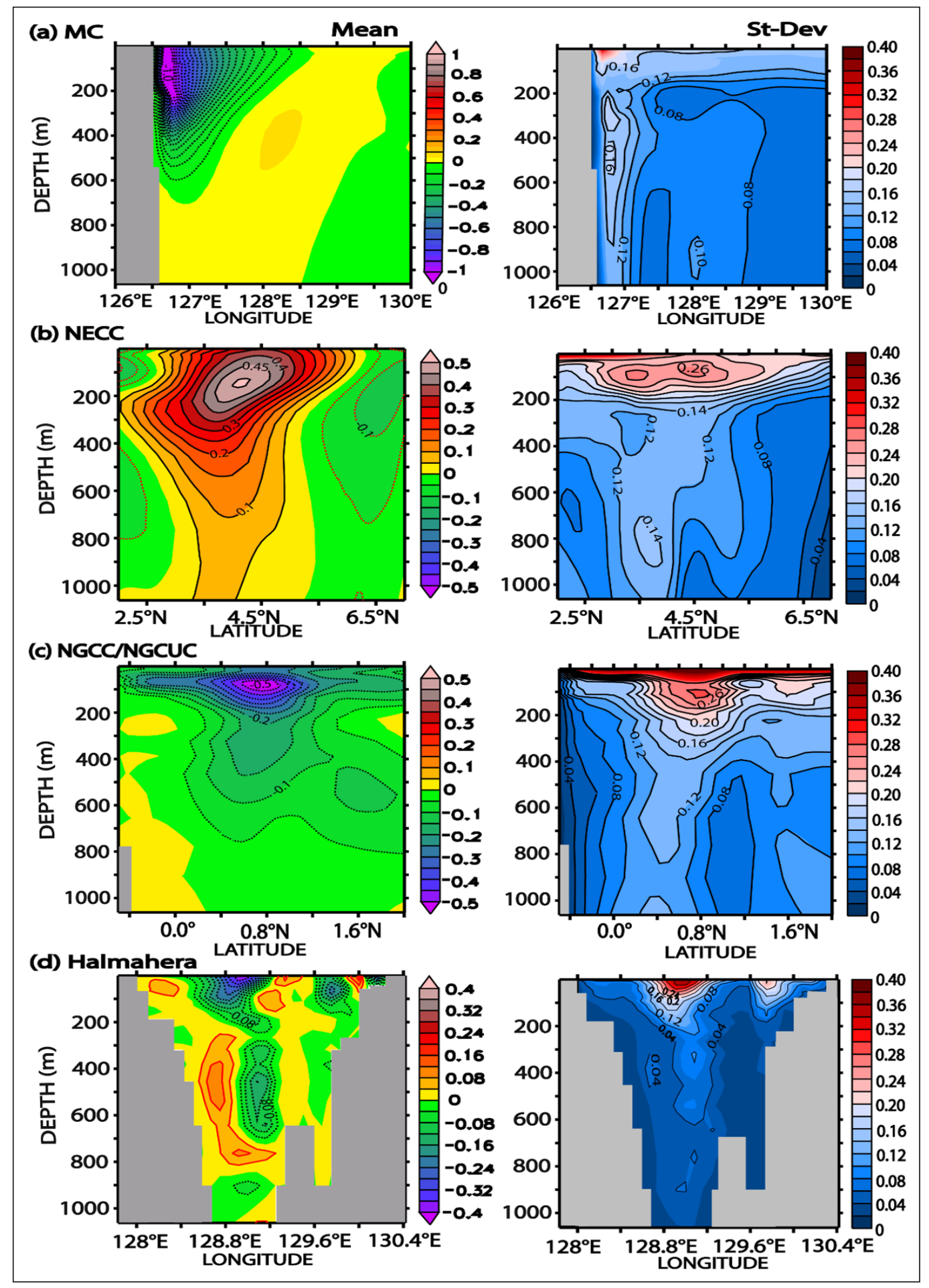

Figure 5. The cross section of mean (left) and standard deviation for (a) MC; (b) NECC, (c) NGCC/NGCUC, and (d) Halmahera throughflow. 
ITF that passes through the Halmahera Sea, covering a width of $67.2 \mathrm{~km}$ (occurring up to a depth of $700 \mathrm{~m}$ ), with the existence of two cores layer around $100 \mathrm{~m}$ and $400 \mathrm{~m}$, the velocities at the sub-surface layer are more significant than a below-thermocline layer, with a maximum velocity of $>0.4 \mathrm{~m} / \mathrm{s}$ from the surface to a depth of $100 \mathrm{~m}$ (Figure $5 \mathrm{~d}$ ). More detailed descriptions about the flow characteristics of MC, NECC, NGCC/NGCUC, and Halmahera throughflow will be further given in the discussion section.

\section{Variability of Volume Transport}

Based on time-series data of volume transport of MC, NECC, NGCC/NGCUC, and Halmahera throughflow from January 2010 to December 2014, the average volume transport of $\mathrm{MC}$ was at the range of $0-50 \mathrm{~Sv}$ (negative value indicates the direction to the south), with an average value of $25.6 \pm 7.1 \mathrm{~Sv}$. MC's annual cycle tended to be stronger in the south before the Southeast monsoon, weakening in the Northwest monsoon (Figure 6a). The average transport estimation of NECC to the east was $34.5 \pm 17.5 \mathrm{~Sv}$. Time-series data from 2010 to 2014 showed increased transport from mid-2013 until the end of 2014. The annual variation showed a maximum transport peak in November and a minimum transport peak in May and June (Figure 6b). Based on time-series data, the average transport of NGCC/NGCUC was $-18.3 \pm 8.3 \mathrm{~Sv}$ (negative value indicates westward flow). The annual variation achieved the maximum transport in November and January and reached the minimum transport in July (Figure 6c). The average transport of Halmahera was 2.5 $\pm 1.8 \mathrm{~Sv}$ to the south. The flow to the south could represent ITF that passed through the Halmahera Sea. Transport variability of Halmahera throughflow achieved the maximum level in October and the minimum level in January (Figure 6d). Temporal variability from time-series transport of MC, NECC, NGCC/NGCUC, and Halmahera throughflow was also found in CWT's analysis result (Figure 7). The CWT for MC, NECC, NGCC/NGCUC, and Halmahera throughflow transport during 2010-2014 showed transport fluctuation in intraseasonal, semiannual (except NECC) annual period. The detailed elaboration of temporal and spatial variability of MC, NECC, NGCC/NGCUC, and Halmahera throughflow transport is presented in the discussion.

Also, the study calculated the transport between Mindanao and Celebes island at the intersection of the Sangihe Ridge and between Sulawesi and the Halmahera in northern Maluku seas. The average volume transports (within the top $600 \mathrm{~m}$ ) in transects across the Sangihe Ridge entrance into the Indonesian seas and across the north Maluku sea into Maluku Sea have values of $8.01( \pm 2.5) \mathrm{Sv}$ and $2.6( \pm 2.1) \mathrm{Sv}$, respectively. The study will not discuss this aspect as this study's scope only focuses on Indonesian throughflow's eastern pathways. At the same time, Pacific inflow through Sangihe Ridge has contributed to ITF's western pathway downstream on Makassar Strait. 


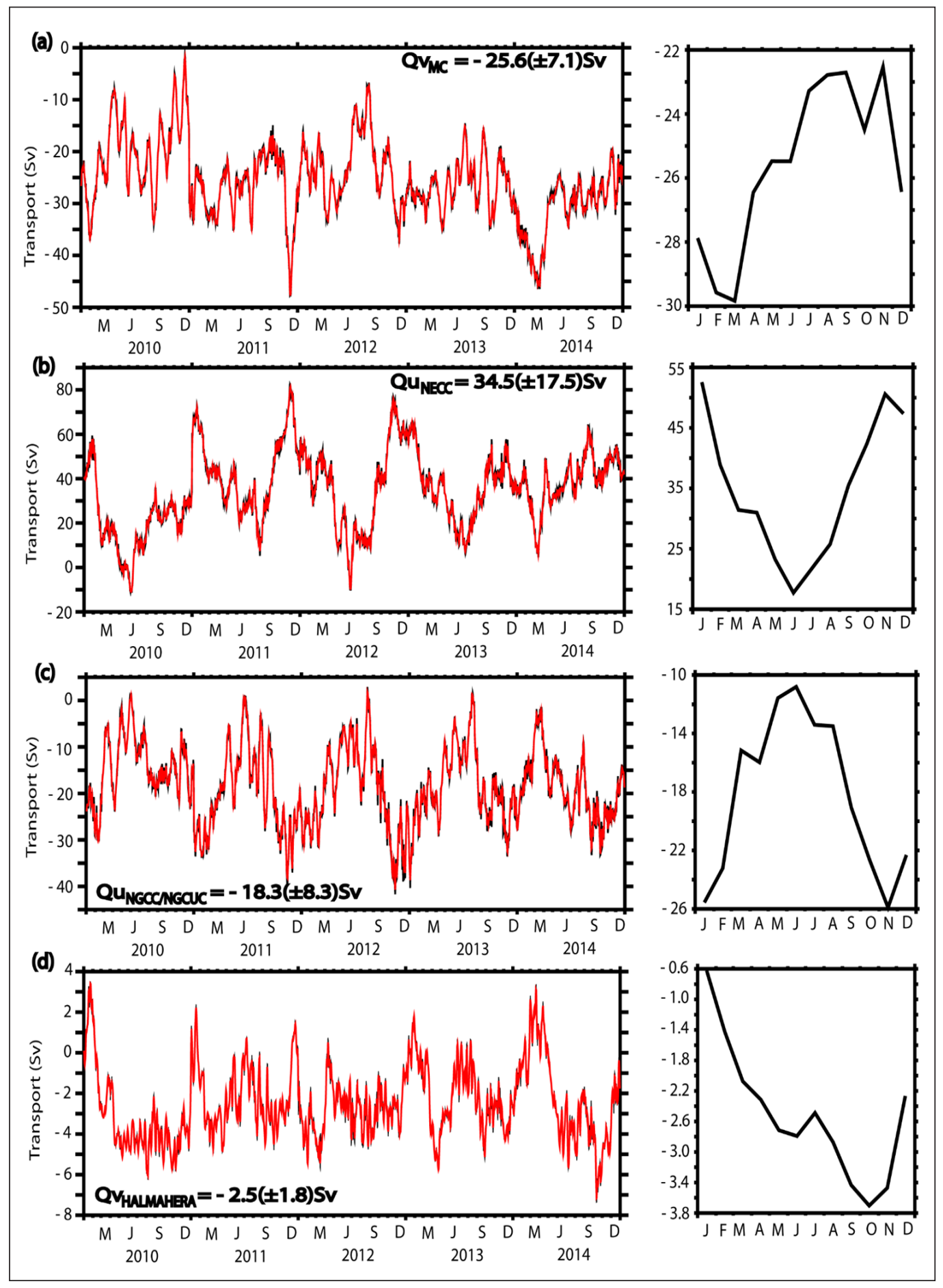

Figure 6. Time-series of volume transport (left) and annual variability (right) of (a) MC; (b) NECC; (c) NGCC/NGCUC; and (d) Halmahera throughflow. Black line indicates daily transport; red line indicates 20-days filtered transport. 


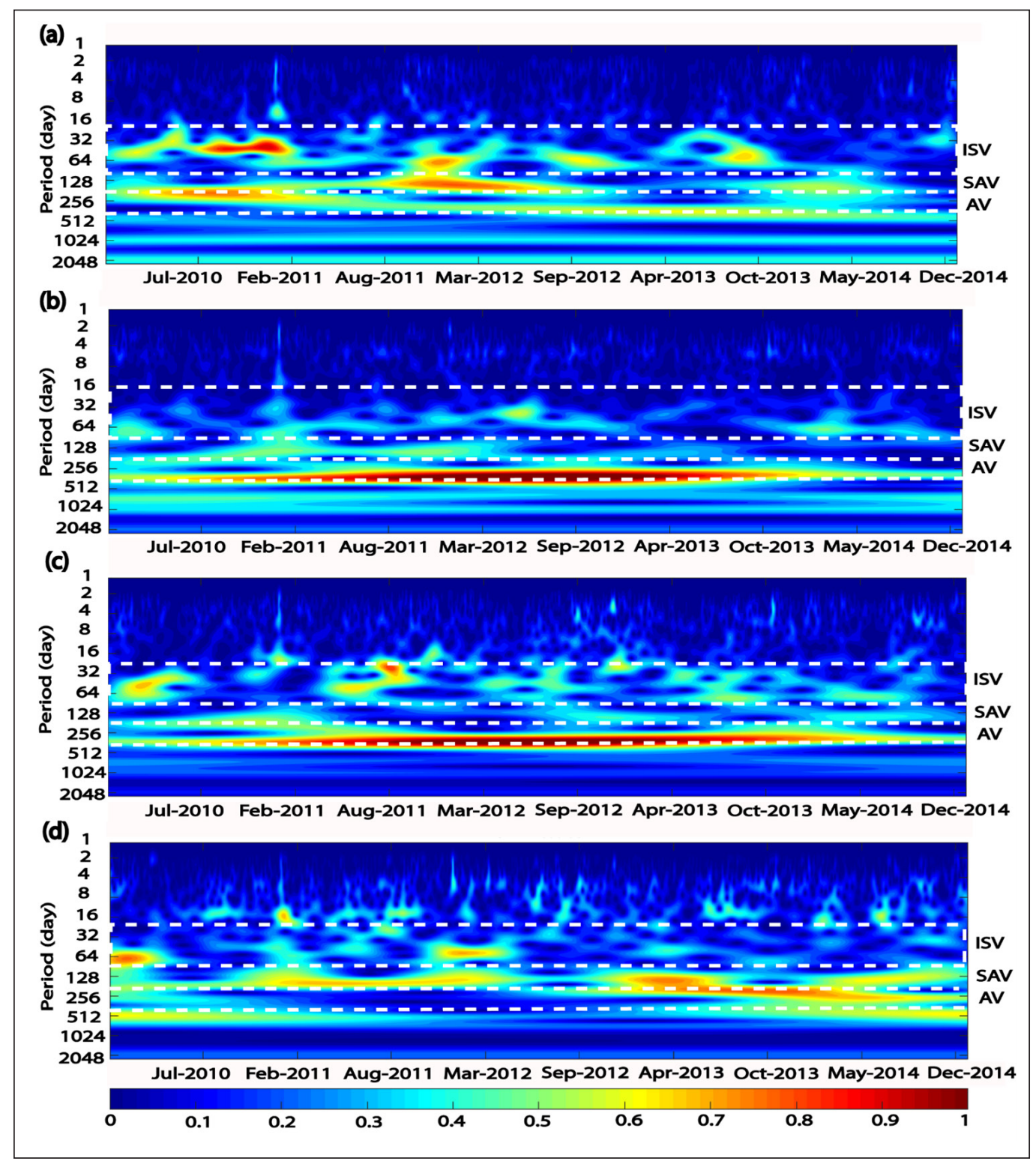

Figure 7. The result of CWT for transport of (a) MC; (b) NECC; (c) NGCC/NGCUC; and (d) Halmahera throughflow. ISV, SAV and AV stand for intraseasonal, semiannual and annual variability, respectively.

\section{Coherence of the Connectivity System in the LLWBC Region and Halmahera} Throughflow

The connection of volume transport between major currents of LLWBC (MC, NECC and NGCC/NGUCC) and Halmahera throughflow based on time series plots of transport anomaly (Figure 8) shows that when MC flows to the south, it is partially supplied to the Sulawesi Sea, while the rest changes direction to Pacific as NECC. NECC and NGCC/ 
NGCUC seem to have a noticeable relationship. The increase in NECC transport leads to a rise in NGCC/NGCUC, considering that the partial flow of NGCC/NGCUC eventually flows as NECC. This condition is also observed in the connection between NGCC/NGCUC transport and Halmahera transport. The anomaly fluctuation of both NGCC/NGCUC and Halmahera transport showed a substantial similarity. The rising transport of NGCC/NGCUC was responsible for the increasing transport of Halmahera. Detail of elaboration related to the transport relationship is presented in the discussion.

The relationship between MC, NECC, NGCC/NGCUC towards Halmahera throughflow transport was apparent in Figure 9 and Table 1. The cross-correlation analysis between time-series data of transport in each area demonstrated the presence of coherence, i.e., MC - NECC, MC - NGCC/NGCUC, MC - Halmahera, NECC - Halmahera, NGCC/ NGCUC - NECC, and NGCC/NGCUC - Halmahera, significant at intraseasonal (20-90 days) and semiannual variabilities. The connection of transport fluctuation of MC - NECC in intraseasonal time-scales, i.e., 49 days and 60 days, contributed to the highest coherence value of 0.8 at 60 days, with a positive phase difference (6.42 days) and current signal in MC preceding NECC. The second highest fluctuation was found at 49-days with a coherence value of 0.79 and a positive phase difference of 3.33 days. The coherence value of $\mathrm{MC}-$ NGCC/NGCUC was found a semiannual period of 93 days and 128 days, i.e., 0.62 and 0.72 , respectively. This output resulted in a positive phase difference of 9.78 days and 10.2 days, with a current signal in MC preceding NGCC/NGCUC. The relationship of transport fluctuation between NGCC/NGCUC and NECC was very close in 171 days and 341 days, as presented by a coherence value of 0.8 (171 days) and 0.79 (341 days). The phase difference was positive, i.e., 10.7 and 23.4 for 171 days and 341 days, respectively, with a current signal in NGCC/NGCUC preceding NECC. The fluctuation of MC Halmahera transport was found at a semiannual period of 114 days and 256 days, with a coherence value of 0.69 and 0.57 and a positive phase difference of 13 days and 22.7 days, respectively. Meanwhile, the current signal was at MC preceding Halmahera throughflow. NECC's fluctuation - Halmahera transport was observed at a semiannual period of 171 days with a coherence of 0.69 . In contrast, both areas' phase difference was at a positive value (12.9 days), with a current signal in NECC preceding Halmahera throughflow. The relationship between fluctuation in NGCC/NGCUC and Halmahera was observed at intraseasonal and semiannual time-scales of 34 days, 43 days, 128 days, and 171 days. The highest coherence $(0.78)$ occurred at 128 days, with a positive phase difference of 14.8 days. Furthermore, the second-highest coherence (0.76) was found at periods of 43 days and 171 days, with a positive phase difference of 5.02 days and 20.3 days. This result suggests that the current NGCC/NGCUC precedes the signal in Halmahera throughflow between 5.02 days and 20.3 days. 


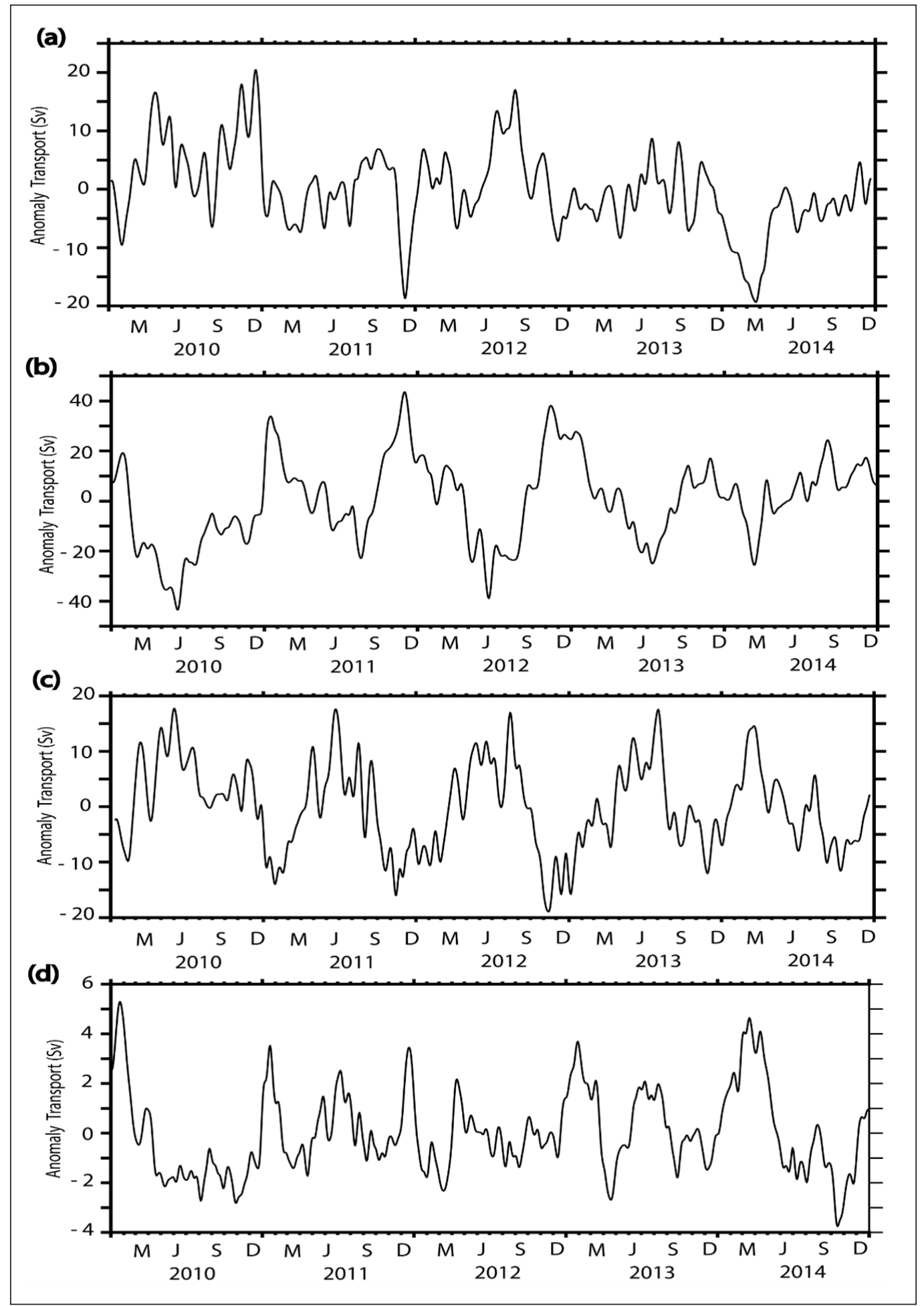

Figure 8. Transport anomaly: (a) MC; (b) NECC; (c) NGCC/NGCUC; and (d) Halmahera. 


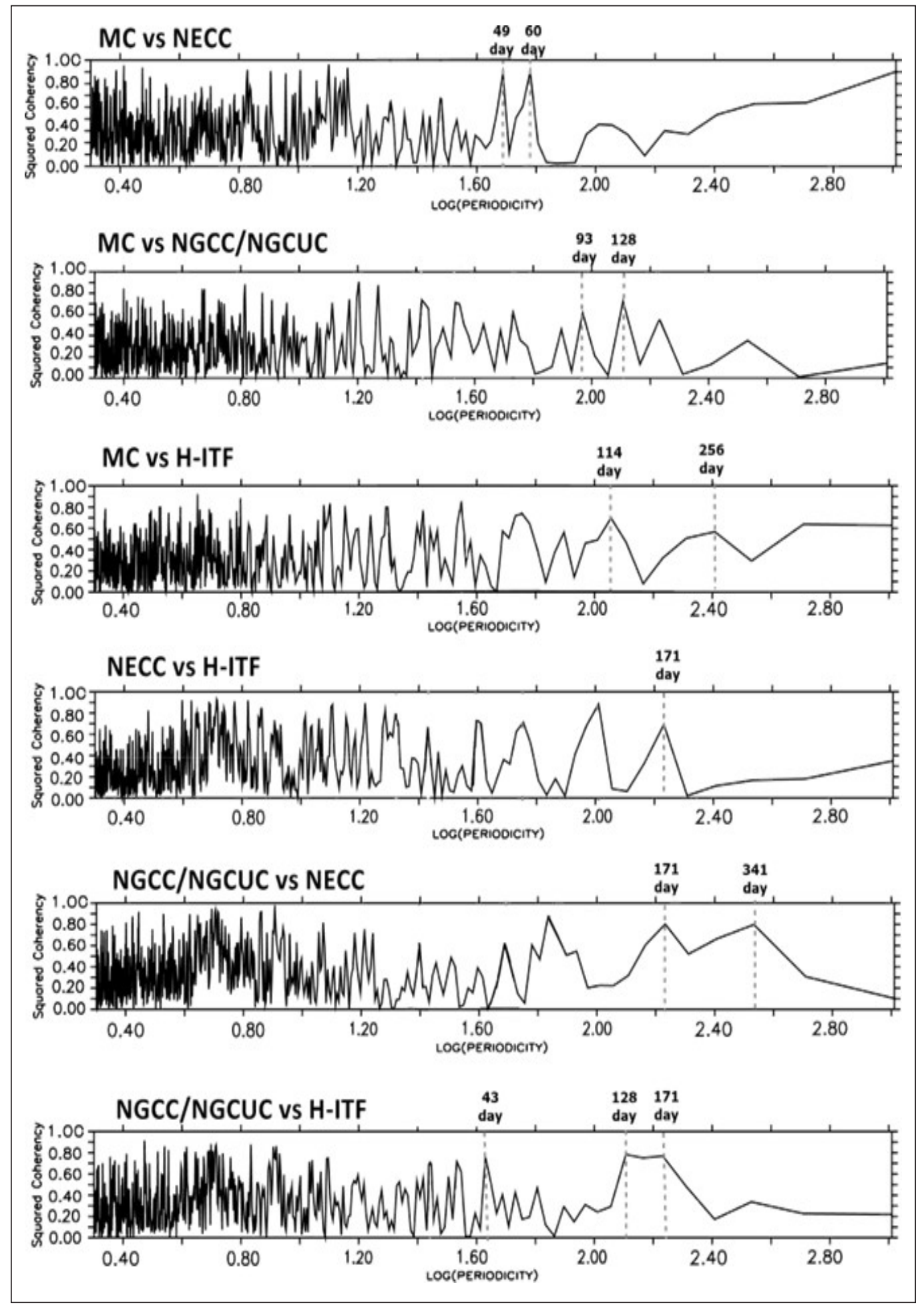

Figure 9. Coherence between MC, NECC, NGCC/NGCUC and Halmahera 
Table 1

Coherence and phase lags observed in MC, NECC, NGCC/NGCUC and Halmahera

\begin{tabular}{lccc}
\hline Cross & $\begin{array}{c}\text { Period } \\
\text { (day) }\end{array}$ & Coherency & $\begin{array}{c}\text { Phase } \\
\text { (day) }\end{array}$ \\
\hline MC - NECC & 49 & 0.79 & 3.33 \\
& 60 & 0.80 & 6.42 \\
MC - NGCC/NGCUC & 93 & 0.62 & 9.78 \\
& 128 & 0.72 & 10.2 \\
MC - Halmahera & 114 & 0.69 & 13 \\
& 256 & 0.57 & 22.7 \\
NECC - Halmahera & 171 & 0.69 & 12.9 \\
NGCC/NGCUC - & 171 & 0.80 & 10.7 \\
NECC & 341 & 0.79 & 23.4 \\
NGCC/NGCUC - & 43 & 0.76 & 5.02 \\
Halmahera & 128 & 0.78 & 14.8 \\
& 171 & 0.76 & 20.3 \\
\hline
\end{tabular}

\section{DISCUSSION}

The LLWBC is an intersection region of the water masses from the North Pacific (NP) and the South Pacific (SP) with distinct characteristics. The characteristics of the NP brought by MC are dissimilar to those from SP brought by NGCC/NGCUC. MC is a part of LLWBC in NP, formed when NEC impairs Philippine's eastern coast (Kashino et al., 1996; Kashino et al., 2013; Kashino et al., 2015). MC transports NP's water mass and mixes them when flowing to the south from the Philippine Sea, supplying the tropical circulation in the North Pacific and Indian Oceans (via ITF). The maximum core velocity of MC from INDESO model data (January 2010 to December 2014 along $7^{\circ} \mathrm{N}$ ) was above $1 \mathrm{~m} / \mathrm{s}$. Kashino et al. (2013) reported that according to SADPC assessment at $7^{\circ} \mathrm{N}$ during a cruise from December 2006 to January 2007, the MC appeared to be very strong with a velocity of $2.0 \mathrm{~m} / \mathrm{s}$. The MC core velocity was high during boreal summers (Kashino et al., 2005). MC almost reached the maximum speed adjacent to $7^{\circ} \mathrm{N}$ with an average rate of $1.2 \mathrm{~m} / \mathrm{s}$ nearby the surface (Qu et al., 2012). The cross-section demonstrates that MC existed on the surface until a depth of $700 \mathrm{~m}$. This result follows a previous report by Qu et al. (2012), finding that $\mathrm{MC}$ disappeared below $600 \mathrm{~m}$. In general, the current flows to the north closely relates to the southeastern anticyclonic eddies from Mindanao. The anticyclonic eddies consequence the slope towards the polar from HE in sub-thermocline ( $\mathrm{Qu}$ et al., 1999). The fluctuation of MC transport was dominant in the annual period. Many studies on MC have focused on intraseasonal (Kashino et al., 2005), semiannual and yearly periods (Kim et al., 2004; Kashino et al., 2009, Kashino et al., 2011; Ren et al., 2018), as a local response to wind perturbation (Wyrtki, 1961; Qu et al., 2012) and remote forcing through propagating to the westward by Rossby waves (Kessler, 1990; Qiu \& Lukas, 1996; Tozuka et al., 2002). 
NECC is a flow originating from West Pacific that flows to the east. It was found to pass through the tropical Pacific between $2^{\circ} \mathrm{N}-10^{\circ} \mathrm{N}$, mainly supplied by Mindanao current, which is recirculation of Mindanao Current from Sulawesi Sea entering the current of New Guinea (Wyrtki \& Kendall, 1967; Lukas \& Lindstrom, 1991; Donguy \& Meyers, 1996; Hsin \& Qiu, 2012; Zhao et al., 2016). The average zonal velocity from the INDESO model along $133^{\circ} \mathrm{N}$ was found to spread between $2^{\circ} \mathrm{N}-6^{\circ} \mathrm{N}$. The core of NECC is found at $4^{\circ} \mathrm{N}$. Donguy and Meyers (1996), obtaining data from expendable bathythermograph (XBT), reported that the NECC center was close to $5^{\circ} \mathrm{N}$ in the western Pacific and shifted to the north about $7^{\circ} \mathrm{N}$ in the center of the Pacific. NECC transport from the INDESO model was 34.5 Sv. Donguy and Meyers (1996) found the NECC transport of $21 \mathrm{~Sv}$. It increased with increasing longitude from east to west. In terms of seasonality, the observed NECC transport is smaller in boreal winter-spring and larger in summer-fall (Johnson et al., 2002; Heron et al., 2006).

NGCC and NGCUC flow along the New Guinea coast, which is a part of South Equatorial Current. The core dimension of NGCC was spread from northern New Guinea up to $2^{\circ} \mathrm{N}$, detected near-surface until $200 \mathrm{~m}$. The maximum speed was $>0.5 \mathrm{~m} / \mathrm{s}$ at a depth of $100 \mathrm{~m}$. NGCUC occurs below NGCC, which flows to the northwest (Kuroda, 2000; Ueki et al., 2003). NGCC flows to the northwest and turns back to the eastern Halmahera Island, joining Mindanao current and then flowing to the east as NECC. The NGCC shows significant seasonal variations related to the monsoon. Ueki et al., (2003) reported that NGCC was stronger in Southeast monsoon than Northwest monsoon. Kuroda (2000) found that NGCC was a surface current caused by seasonal influences. Although the direction of NGCC varies on a seasonal basis (Wyrtki, 1961), it consistently flows towards the equatorial line. The subsurface NGCUC also changes seasonally, but the current direction does not change throughout the year (Kuroda, 2000; Ueki et al., 2003). During Southeast monsoon, NGCUC is strongly transported to the northwest (Kashino et al., 2007).

Halmahera throughflow reached $150 \mathrm{~m}$ in depth with a maximum speed of $>0.4 \mathrm{~m} / \mathrm{s}$ from the surface to the depth of $100 \mathrm{~m}$. The average transport of Halmahera current was $2.5 \mathrm{~Sv}$, achieving the maximum value in September and October and minimum value in January. The fluctuation of Halmahera transport was dominated by semiannual (180 days) and intraseasonal (20 - 90 days) periods, followed by an annual period. The volume transport of ITF was higher in Southeast monsoon (May - September) than the Northeast Monsoon (October-March). This result was consistent with previous studies (Potemra, 2005, Sprintall et al., 2009). In the Monsoon break (October - November), Halmahera throughflow's velocity begins to diminish because changes in direction from the Southeast shifts to the Northwest monsoon winds, thus directing Ekman transport to the north (Wyrtki, 1961). The physical characteristics of water mass (temperature, salinity, and current) from observation data in Halmahera seas are relatively scarce. Cresswell \& Luick (2001), after measurement using current mooring meter at a depth of $400 \mathrm{~m}, 700 \mathrm{~m}$, and $900 \mathrm{~m}$ in the 
Halmahera Sea, reported that the current in each depth level demonstrated distinct velocity direction. Nevertheless, the current change in the Halmahera Sea was dominantly influenced by NGCC. Wattimena et al. (2018) showed coherency in the transport volume between Halmahera throughflow and NGCC in the upper $200 \mathrm{~m}$ depth from daily INDESO model output (2008-2014). They found the mean volume transport of Halmahera throughflow was $2.35( \pm 1.94) \mathrm{Sv}$ (southward), and volume transport of NGCC was $13.47( \pm 6.6) \mathrm{Sv}$ (westward). The model indicated that Halmahera throughflow is supplied by $17.45 \%$ of NGCC.

Transport of MC, NECC, NGCC/NGCUC, and Halmahera throughflow displays a clear connection but very complicated. The schematic of average transport LLWBC and partitions to Indonesian seas based on the INDESO model are presented in Figure 10. Likewise, this pattern can also be seen in anomaly transport shown in Figure 8 in which the intensified MC increases NECC transport. A rising in the transport of NGCC leads to an increase in NECC transport. This aspect is explainable since the change in the direction of NGCC flow also contributed to NECC. This aspect also explains the connection between NGCC and Halmahera transport. With increasing NGCC transport, Halmahera transport was also rose. The comparisons of the estimations of volume transport of MC, NECC, NGCC/NGCUC and Halmahera throughflow between this current study and previous work are shown in Table 2. Burnett et al. (2003) reported that NECC transport flow increased with the decreasing MC transport entering the Sulawesi Sea. The role of NGCC to induce transport to Halmahera could be observed during Southeast monsoon, in which wind stress is almost in line with the NGCC direction. This aspect strengthens Ekman flow along the New Guinea coast, contributing to elevating transport to Halmahera. The roles of $\mathrm{MC}$, NECC, NGCC/NGCUC, and Halmahera throughflow were in a strong relationship as they affected the water mass transport passing through Halmahera throughflow. MC transport to the south affects NECC transport.

Similarly, NECC transport is also affected by NGCC/NGCUC transport. The reversed direction of NGCC in the northeast of Halmahera Island eventually joins with reversal MC current, then flowing to the east as NECC. The relationship between transport of MC - NECC was found to have the highest coherence (0.8) at 60 days, with a positive phase difference (6.42 days) and current signal in MC preceding NECC up to 6.42 days. The shifting of NGCC/NGCUC into NECC in the northeast of Halmahera Island generated Halmahera Eddies (HE), also contributed to regulate the composition of ITF passing through the east gate (Aruda \& Nof, 2003; Kashino et al., 2013; Harsono et al., 2014). The connection of transport fluctuation between NGCC/NGCUC - NECC was strongly correlated, as indicated by the highest coherence value (0.8) for 171 days with a positive phase difference of 10.7 days, meaning that signal in NGCC/NGCUC is preceding NECC up to 10.7 days. Transport of water mass to Halmahera through the east gate of ITF 


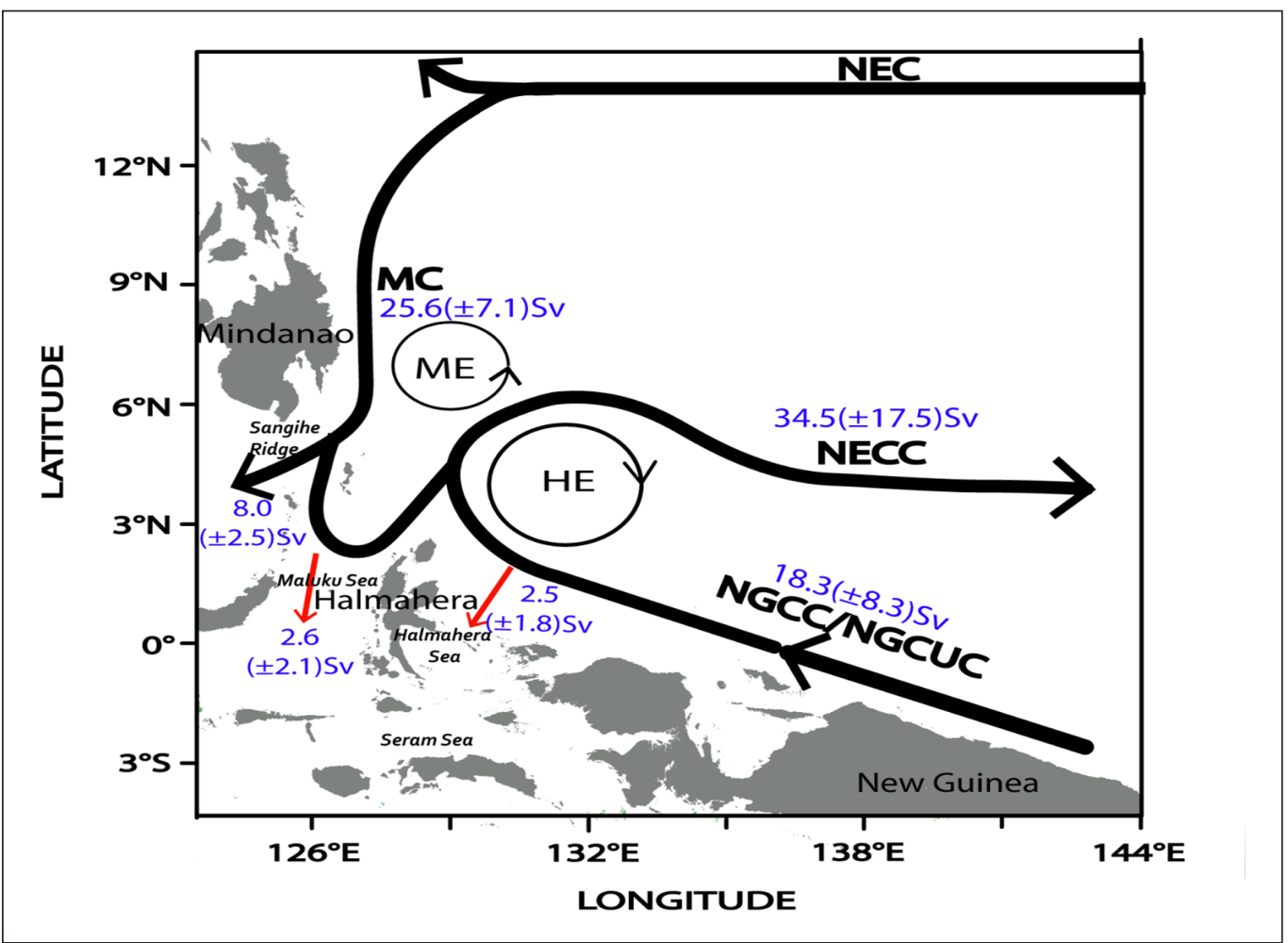

Figure 10. Schematic description of LLWBC. The blue value represents the transport of MC, NECC, NGCC/ NGCUC and Halmahera throughflow, Sangihe Ridge and north Maluku Sea

Table 2

Comparison of LLWBCs system transport estimates between INDESO output model (this study) and past studies

\begin{tabular}{lll}
\hline Ocean Current & This Study & \multicolumn{1}{c}{ Past Studies } \\
\hline NECC & $25.6( \pm 7.1) \mathrm{Sv}$ & $15-20 \mathrm{~Sv}$ (Webb, 2018) \\
& & $10-30 \mathrm{~Sv}$ (Gouriou \& Toole, 1993); Johnson et al., 2002); \\
& Wyrtki \& Kendall, 1967) \\
& $21 \mathrm{~Sv}$ (Donguy \& Meyers, 1996) \\
& & $8-40 \mathrm{~Sv}$ (Lukas, 1988) \\
& $31 \mathrm{~Sv}$ (Kashino et al., 2009) \\
MC & $27.5( \pm 17.5) \mathrm{Sv}$ (Qu et al., 1998) \\
& & $9-18 \mathrm{~Sv}$ (Lindstrom et al., 1990) \\
& & $11-32 \mathrm{~Sv}$ (Kuroda, 2000) \\
NGCC/ & $13.47 \mathrm{~Sv}$ (Wattimena et al., 2018) \\
NGCUC & $3.3( \pm 8.3) \mathrm{Sv}$ (Morey et al., 1999) \\
& & $1.5 \mathrm{~Sv}$ (Cresswell \& Luick, 2001) \\
Halmahera & $2.2 \mathrm{~Sv}$ (Potemra et al., 2003) \\
& $2.35 \mathrm{~Sv}$ (Wattimena et al., 2018) \\
& &
\end{tabular}


was dominantly affected by NGCC/NGCUC transport. The coherence analysis result demonstrates that the phase difference of signal fluctuation between NGCC/NGCUC and Halmahera throughflow was at a range of 0.76 and 0.78 , with a positive phase difference of 5.02 days to 20.3 days. This result suggests that the signal fluctuation of NGCC/NGCUC flowing to Halmahera throughflow takes between 5.02 days and 20.3 days, indicating the presence of the Rossby wave's signal propagation in the Halmahera Sea.

\section{CONCLUSION}

The present study examined the vertical structures and their volume transport variabilities in the western equatorial Pacific current system (LLWBC). In particular, it looked at the coherence between the northwestward NGCC/NGCUC and Halmahera throughflow.

The conclusions of the present study can be summarized as follows:

1. MC is characterized by a core current occupying the surface layer to $250 \mathrm{~m}$ with a maximum current larger than $1 \mathrm{~m} / \mathrm{s}$. The core current of NGCC is located at the top $200 \mathrm{~m}$ with a maximum current larger than $0.5 \mathrm{~m} / \mathrm{s}$, while NGCUC exists below the core current of NGCC. The maximum currents of the cores of MC and NGCC/NGCUC are visible in the NECC current structure. NECC's core is present within the top $300 \mathrm{~m}$ with a maximum speed larger than $0.5 \mathrm{~m} / \mathrm{s}$.

2. Likewise, the maximum current of the core of NGCC/NGCUC is present in the ocean current's vertical structure in the Halmahera throughflow. Halmahera throughflow is characterized by two cores of current located within the top $100 \mathrm{~m}$ and around $400 \mathrm{~m}$. The shallow core current has a stronger ocean current $(>0.4$ $\mathrm{m} / \mathrm{s}$ ) compared to that in the deep core (up to $0.2 \mathrm{~m} / \mathrm{s}$ ).

3. There are strong relationships between NGCC/NGCUC and Halmahera throughflow based on the coherence value (coefficient coherence: $\sim 0.8$ ). This high coherence is positively related to Halmahera throughflow directly connected to NGCC/NGCUC. Based on this coherence analysis, the variability of NGCC/NGCUC will affect Halmahera throughflow after 5 to 20 days (i.e., the phase difference).

\section{ACKNOWLEDGMENTS}

The authors are very grateful to the INDESO project of the Indonesian Ministry of Marine Affairs and Fisheries for the data, the Group for High-Resolution Sea Surface Temperature (SST) (GHRSST) (https://www.ghrsst.org/ghrsst-data-services/products/), Segment Sol Multi missions d'Altimétrie, d'Orbitographie et de localization precise (SSALTO) and the Data Unification and Altimetry Combination System (DUACS) for the sea surface height anomaly (SSHA) data (http://aviso.oceanobs.com/duacs/), and INDOMIX program for the near-bottom current velocity data from ADCP. They also thank the Anonymous Reviewers, whose comments helped in the improvement of the manuscript. 


\section{REFERENCES}

Arruda, W. Z., \& Nof, D. (2003). The Mindanao and Halmahera eddies: Twin eddies induced by nonlinearities. Journal of Physical Oceanography, 33(12), 2815-2830. https://doi.org/10.1175/15200485(2003)033<2815:TMAHEE >2.0.CO;2

Atmadipoera, A., Koch-Larrouy, A., Cuypers, Y., Molcard, R., Jaya, I., \& Harsono, G. (2013, June 24-27). New current measurement in the Halmahera Passage, Indonesia [Poster Presentation]. Asian Oceania Geosciences Society Symposium, Australia.

Atmadipoera, A., Kuroda, Y., Pariwono, J. I., \& Purwandana, A. (2004). Water mass variation in the upper layer of the Halmahera eddy region observed from a TRITON buoy. The Institute of Electrical and Electronics Engineers, 3, 1496-1503. https://doi.org/10.1109/OCEANS.2004.1406342

Bahurel, P., \& Mercator, P. T. (2006). Mercator ocean global to regional ocean monitoring and forecasting. In E. P. Chassignet \& J. Verron (Ed.), Ocean weather forecasting (pp. 381-395). Springer.

Bendat, J. S., \& Piersol, A. G. (2010). Random data analysis and measurement procedure. John Wiley and Sons Inc.

Burnett, W. H., Kamenkovich, V. M., Gordon, A. L., \& Mellor, G. L. (2003). The Pacific/Indian Ocean pressure difference and its influence on the Indonesian Seas circulation: Part I-The study with specified total transports. Journal of Marine Research, 61(5), 577-611. https://doi.org/10.1357/002224003771815963

Cresswell, G. R., \& Luick, J. L. (2001). Current measurement in the Halmahera Sea. Journal of Geophysical Research, 106(C7), 13945-13952. https://doi.org/10.1029/2000JC000688

Donguy, J. R., \& Meyers, G. (1996). Mean annual variation of transport of major currents in the tropical Pacific Ocean. Deep Sea Research, Part I, 43(7), 1105-1122. https://doi.org/10.1016/0967-0637(96)00047-7

Emery, W., \& Thomson, R. E. (2014). Data analysis methods in physical oceanography (3rd Ed.). Elsevier Science.

Fine, R. A., Lukas, R., Bingham, F., Warnar, W., \& Gammon, R. (1994). The western equatorial Pacific: A water mass crossroads. Journal of Geophysical Research, 99, 25063-25080. https://doi.org/10.1029/94JC02277

Gordon, A. L. (2005). Oceanography of the Indonesian seas and their throughflow. Oceanography, 18(4), 14-27.

Gordon, A. L., \& Fine, R. (1996). Pathways of water between the Pacific and Indian oceans in the Indonesian seas. Nature, 379(6561), 146-149. https://doi.org/10.1038/379146a0

Gouriou, Y., \& Toole, J. (1993). Mean circulation of the upper layers of the western equatorial Pacific Ocean. Journal of Geophysical Research, 98(C12), 22495-22520. https://doi.org/10.1029/93JC02513

Harsono, G., Atmadipoera, A. S., Syamsudin, F., Manurung, D., \& Mulyono, S. B. (2014). Halmahera eddy features observed from multisensor satellite oceanography. Asian Journal of Scientific Research, 7(4), 571-580. https://doi.org/10.3923/ajsr.2014.571.580

Heron, S. F., Metzger, E. J., \& Skirving, W. J. (2006). Seasonal variations of the ocean surface circulation in the vicinity of Palau. Journal of Oceanography, 62(4), 413-426. https://doi.org/10.1007/s10872-006-0065-3 
Hsin, Y. C., \& Qiu, B. (2012). Seasonal fluctuations of the surface North Equatorial Counter Current (NECC) across the Pacific basin. Journal of Geophysical Research, 117, Article C06001. https://doi. org/10.1029/2011JC007794

Hu, D., Wu, L., Cai, W., Gupta, A. S., Ganachaud, A., Qiu, B., Gordon, A. L., Lin, X., Chen, Z., Hu, S., \& Wang, G. (2015). Pacific western boundary currents and their roles in climate. Nature, 522(7556), 299308. https://doi.org/10.1038/nature14504

Ilahude, A. G., \& Gordon, A. L. (1996). Thermocline stratification within the Indonesian seas. Journal of Geophysical Research, 101(12), 401-409. https://doi.org/10.1029/95JC03798

Johnson, G. C., Sloyan, B. M., Kessler, W. S., \& McTaggart, K. E. (2002). Direct measurements of upper ocean currents and water properties across the tropical Pacific during the 1990s. Progress in Oceanography, 52(1), 31-61. https://doi.org/10.1016/S0079-6611(02)00021-6

Kashino, Y., Aoyama, M., Kawano, T., Hendiarti, N., Anantasena, Y., Muneyama, K., \& Watanabe, H. (1996). The water masses between Mindanao and New Guinea. Journal of Geophysical Research, 101(12), 391 12,400. https://doi.org/10.1029/95JC03797

Kashino, Y., Atmadipoera, A. S., Kuroda, Y., \& Lukijanto. (2013). Observed feature of the Halmahera and Mindanao Eddies. Journal of Geophysical Research Oceans, 118, 6543-6560. https://doi. org/10.1002/2013JC009207

Kashino, Y., Espana, N., Syamsudin, F., Richards, K., Jensen, T., Dutrieux, P., \& Ishida, A. (2009). Observations of the North Equatorial Current, Mindanao Current, and Kuroshio current system during the 2006/07 El Nino and 2007/08 La Nina. Journal of Oceanography, 65, 325-333. https://doi.org/10.1007/s10872009-0030-Z

Kashino, Y., Firing, E., Hacker, P., Sulaiman, A., \& Lukiyanto. (2001). Currents in the Celebes and Maluku Seas, February 1999. Geophysical Research Letters, 28, 1263-1266. https://doi.org/10.1029/2000GL011630

Kashino, Y., Ishida, A., \& Hosoda, S. (2011) Observed ocean variability in the Mindanao Domeregion. Journal of Physical Oceanography, 41, 287-302. https://doi.org/10.1175/2010JPO4329.1

Kashino, Y., Ishida, A., \& Kuroda, Y. (2005). Variability of the Mindanao current: Mooring observation results. Geophysical Research Letters, 32, Article L18611. https://doi.org/10.1029/2005GL023880

Kashino, Y., Ueki, I., \& Sasaki, H. (2015). Ocean variability east of Mindanao: Mooring observations at 7N. Journal of Geophysical Research Oceans, 120, 2540-2554. https://doi.org/10.1002/2015JC010703

Kashino, Y., Ueki, I., Kuroda, Y., \& Purwandana, A. (2007). Ocean variability north of New Guinea derived from TRITON buoy data. Journal of Oceanography, 63, 545-559. https://doi.org/10.1007/s10872-007-0049-y

Kessler, W. S. (1990). Observations of long Rossby waves in the northern tropical Pacific. Journal of Geophysical Research: Oceans, 95(C4), 5183-5217. https://doi.org/10.1029/JC095iC04p05183

Kim, Y. Y., Qu, T., Jensen, T., Miyama, T., Mitsudera, H., Kang, H. W., \& Ishida, A. (2004). Seasonal and interannual variations of the North Equatorial Current bifurcation in a high-resolution OGCM. Journal of Geophysical Research: Oceans, 109(C3). https://doi.org/10.1029/2003JC002013 
Kuroda, Y. (2000) Variability of the currents off the north coast of New Guinea. Journal of Oceanography, 56, 103-106. https://doi.org/10.1023/A:1011122810354

Lindstrom, E., Butt, J., Lukas, R., \& Godfrey, S. (1990). The flow through Vitiaz Strait and St. George's Channel, Papua New Guinea. In L. Pratt (Ed.) The physical oceanography of sea straits, (pp. 171-189). Kluwer Academic Publisher.

Lukas, R. (1988). Interannual fluctuations of the Mindanao Current in ferred from sea level. Journal of Geophysical Research, 93, 6744-6748. https://doi.org/10.1029/JC093iC06p06744

Lukas, R., \& Lindstrom, E. (1991). The mixed layer of the western equatorial Pacific Ocean. Journal of Geophysical Research, 96(S01), 3343-3357. https://doi.org/10.1029/90JC01951

Lukas, R., Yamagata, T., \& McCreary, J. P. (1996). Pacific low latitude western boundary currents and the Indonesian throughflow. Journal of Geophysical Research Oceans, 101, 12209-12216. https://doi. org/10.1029/96JC01204

Morey, S. L., Shriver, J. F., \& O’Brien, J. J. (1999). The effects of Halmahera on the Indonesian Throughflow. Journal of Geophysical Research, 104, 23281-23296. https://doi.org/10.1029/1999JC900195

Potemra, J. T. (2005). Indonesian throughflow transport variability estimated from satellite altimetry. Oceanography, 18(4), 98-107.

Potemra, J. T., Hautala, S. L., \& Sprintall, J. (2003). Vertical structure of Indonesian throughflow in a large-scale model. Deep Sea Research II, 50(12-13), 2143-2162. https://doi.org/10.1016/S0967-0645(03)00050-X

Qiu, B., \& Lukas, R. (1996). Seasonal and interannual variability of the North Equatorial Current, the Mindanao Current, and the Kuroshio along the Pacific western boundary. Journal of Geophysical Research: Oceans, 101(C5), 12315-12330. https://doi.org/10.1029/95JC03204

Qu, T. H., Mitsudera, H., \& Yamagata, T. (1999). A climatology of the circulation and water mass distribution near the Philippine coast. Journal of Physical Oceanography, 29(7), 488-1505. https://doi. org/10.1175/1520-0485(1999)029<1488:ACOTCA>2.0.CO;2

Qu, T. H., Mitsudera, H., \& Yamagata, T. (1998). On the western boundary currents in the Philippine Sea. Journal of Geophysical Research, 103(C4), 7537-7548. https://doi.org/10.1029/98JC00263

Qu, T., Chiang, T., Wu, C., Dutrieux, P., \& Hu, D. (2012). Mindanao current/undercurrent in an eddy-resolving GCM. Journal of Geophysical Research, 117(C6), Article C06026. https://doi.org/10.1029/2011JC007838

Ren, Q., Li, Y., Wang, F., Song, L., Liu, C., \& Zhai, F. (2018). Seasonality of the Mindanao current/ undercurrent system. Journal of Geophysical Research Oceans, 123(2), 1105-1122. https://doi. org/10.1002/2017JC013474

Sprintall, J., Wijffels, S. E., Molcard, R., \& Jaya, I. (2009). Direct estimates of the Indonesian throughflow entering the Indian Ocean: 2004-2006. Journal of Geophysical Research, 114(c7), Article C07001. https:// doi.org/10.1029/2008JC005257

Theetten, S., Thiebaul, B., Dumas, F., \& Paul, J. (2014). Bmgtools: A community tool to handle model grid and bathymetry. Mercator Ocean-Quarterly Newsletter, (49), 94-98. 
Tozuka, T., Kagimoto, T., Masumoto, Y., \& Yamagata, T. (2002). Simulated multiscale variations in the western tropical Pacific: The Mindanao Dome revisited. Journal of Physical Oceanography, 32(5), 1338-1359. https://doi.org/10.1175/1520-0485(2002)032<1338:SMVITW>2.0.CO;2

Tranchant, B., Reffray, G., Greiner, E., Nugroho, D., Koch-Larrouy, A., \& Gaspar, A. (2015). Evaluation of an operational ocean model configuration at $1 / 12^{\circ}$ spatial resolution for the Indonesian seas (NEMO2.3/ INDO12) - Part 1: Ocean physics. Geoscientific Model Development, 9(3), 1037-1064. https://doi. org/10.5194/gmd-9-1037-2016

Ueki, I., Kashino, Y., \& Kuroda, Y. (2003). Observation of current variations off the New Guinea coast including the 1997-1998 El Ni no period and their relationship with Sverdrup transport. Journal of Geophysical Research, 108(C7), Article 3243. https://doi.org/10.1029/2002JC001611

Wattimena, M. C., Atmadipoera, A. S., Purba, M., Nurjaya, I. W., \& Syamsudin, F. (2018). Indonesian throughflow (ITF) variability in Halmahera Sea and its coherency with New Guinea Coastal current. IOP Conference Series: Earth and Environmental Science, 176(1), Article 012011. https://doi. org/10.1088/1755-1315/176/1/012011

Webb, D. J. (2018). On the role of the North Equatorial counter current during a strong El Niño. Ocean Science, 14(4), 633-660.

Wijffels, S., Firing, E., \& Toole, J. (1995). The mean structure and variability of the Mindanao Current at $8^{\circ} \mathrm{N}$. Journal of Geophysical Research: Oceans, 100(C9), 18421-18435. https://doi.org/10.1029/95JC01347

Wyrtki, K. (1961). Physical oceanography of the Southeast Asian Waters. NAGA Report 2 Scripps Inst.

Wyrtki, K., \& Kendall, R. (1967). Transports of the Pacific equatorial countercurrent. Journal of Geophysical Research, 72(8), 2073-2076. https://doi.org/10.1029/JZ072i008p02073

Zhao, J., Li, Y. L., \& Wang, F. (2016). Seasonal fluctuations of the WPO surface NECC. Chinese Journal of Oceanology and Limnology, 34(6), 1332-1346. 
